\title{
Preparing Students for Education, Work, and Community: Activity Theory in Task-Based Curriculum Design
}

\section{Chris Campbell, Seonaigh MacPherson, E Tanis Sawkins}

This case study describes how sociocultural and activity theory were applied in the design of a publicly funded, Canadian Language Benchmark (CLB)-based English as a Second Language (ESL) credential program and curriculum for immigrant and international students in postsecondary institutions in British Columbia, Canada. The ESL Pathways Project was conceived to prepare immigrant students to navigate the multiple pathways in the settlement process from postsecondary education to the workplace, community participation, and citizenship. The innovation in curriculum design resulted from the systematic reinterpretation of situated cognition and task-based design using activity theory. Given that both situated and task-based learning share intersecting theoretical lineages with activity theory, this reinterpretation was more a deepening and improvement than a reconceptualization process. The ensuing units were defined by the real-world activities and contexts of target communities of practice, with relevant instructional topics, tasks, genres, skills, and outcomes presented in a systematic manner to support learners to participate, ultimately, in those target communities. This process contrasts with traditional ad hoc forms of task-based curriculum design in ESL and EAP (English for Academic Purposes).

Cette étude de cas décrit dans quelle mesure la théorie socioculturelle et la théorie de l'activité ont joué un rôle dans la conception d'un programme d'étude à crédits pour l'anglais langue seconde reposant sur les niveaux de compétence canadiens et visant les immigrants et les étudiants internationaux dans les institutions postsecondaires en Colombie britannique au Canada. Le projet "ESL Pathways » (Parcours en anglais langue seconde) a été conçu pour aider les étudiants immigrants à naviguer les divers parcours que présente le processus d'établissement, depuis les études postsecondaires à la citoyenneté en passant par le milieu du travail et la participation communautaire. Le programme novateur résulte d'une réinterprétation systématique, par le biais de la théorie de l'activité, de la conception située et centrée sur les tâches. Puisque la cognition située et l'apprentissage basé sur les tâches partagent des éléments de la théorie de l'activité, cette réinterprétation représente plutôt un approfondissement et une amélioration qu'une reconceptualisation. Les unités qui en découlent reposent sur des activités réelles et des communautés de pratiques cibles, et elles présentent des thèmes, des tâches, des genres, des habiletés et des résultats de façon systématique de sorte à favoriser la participation des apprenants à ces communautés. Ce processus se distingue des formes traditionnelles et ad hoc de conception des programmes d'étude en anglais langue seconde et en anglais académique. 
Task-based approaches to curriculum design emerged in the 1980s and 1990s with the communicative language teaching revolution, which shifted the focus of language learning from linguistic elements of the formal language system to communicative competence. After the 1990s, Hedge (2000) noted that

the concern with how learners can use and develop their communicative ability in addition to acquiring language knowledge of various kinds has led to the process approach to course design ... [in which] the focus is not so much on what learners need to cover but on how they acquire language through performing it in the classroom. (p. 359)

While the value of this shift in the practice of language teaching and curriculum for learners' language acquisition remains hotly debated (e.g., Ellis, 2009; Swan, 2005), curriculum designers continue to struggle to develop wellinformed models of task-based instruction to realize the full benefits of sociocultural theory for language learning. To this end, designers need to identify and employ an overarching organizing principle for the design process and for synthesizing multiple elements (i.e., language/structures, topics/content, tasks/situations, functions, notions, skills) as learning outcomes, tasks, and units so as to best support learners (Hedge, 2000).

In the case of the ESL Pathways Project, the curriculum design team identified activity theory as a more effective integrative organizing principle for curriculum design than that of "task-based design" alone because it guided the systematic development of clusters of learning experiences that approximated and approached real-world contexts. The curricular encounter of students with target activities was arranged on a spectrum from hypothesized, simulated activities on the one end to real-world activities on the other, wherein both instructors and learners were explicitly supported to synthesize multiple learning outcomes within tasks, genres, and experiential learning opportunities. Too often, ESL/EAP (English for Academic Purposes) programs and curriculum designers are left to design curricula in isolation, with limited time, funds, and access to research or resources on target disciplinary or occupational communities of practice. As a consequence, the presentation and sequencing of language and tasks are often ad hoc and lack the functional integration of language, genres, tasks, interactions, cultures, and activities found in real-world contexts. This curriculum design project, in contrast, pooled research and resources, both as a publicly funded project and as a collaboratively designed curriculum with a design team from a range of EAP, disciplinary, and professional backgrounds. Furthermore, the curriculum targeted three overarching communities of practice to reflect their overlapping yet distinctive language and social experiences: postsecondary education, the workplace, and the community. At the same time, the focus of curricular decision-making was not limited to tasks or genres but extended to 
the sequencing of explicit topics, themes, and contexts to remind both instructors and learners of the contextual demands, constraints, and disjunctures facing the transfer of learning within real-world contexts. The curriculum package presented and reinforced the teaching and learning of relevant sociocultural contexts by providing explicit instructor and learner self-assessment checklists and notes in each unit. These self-assessment tools encouraged instructors and learners alike to participate in informal or nonformal professional development and learning, respectively. Likewise, experiential capstone courses for each credential placed learners in target English-speaking communities of practice to demonstrate their ability to navigate real-world contexts.

This curriculum design process went beyond traditional approaches to ESL task-based or EAP curriculum design, which have a tendency to focus narrowly on target tasks or genres (Dias, 2000; Dias, Freedman, Medway, \& Paré, 1999; Raymond \& Parks, 2002; Swales, 1990, 1996). Instead, this activitybased design attempted to reflect and approximate the demands of the real world. Specifically, the curriculum design process systematically applied sociocultural and activity theory in the needs analysis phase, in the multilevel framework, and in the design of individual units, tasks, and courses in order to enhance connections with real-world communities of practice. While ESL Pathways draws inspiration from similar examples in the guidelines of the Common European Framework and the model of the British Council EQUALS curriculum, this curriculum represents the only example of such an approach in Canada.

\section{The Challenges}

Four key challenges, profiled herein, motivated the innovative approach to curriculum design presented in this article: (a) the internationalization of higher education, (b) the need to accommodate increasing numbers of linguistically and culturally diverse learners, (c) the need to address contextual needs beyond disciplinary knowledge, and (d) the shift to outcomes- or competency-based instructional design and assessment.

\section{Internationalizing Higher Education}

The Association of University and Colleges of Canada (AUCC, 2009) examined the internationalization of curriculum in Canadian universities and concluded that "although the value of internationalization is recognized by Canadian universities, and this interest is increasingly backed with concrete measures and investments, integrating an international dimension into the curriculum has been a more challenging endeavour" (p. 7). The AUCC report identified the following components of university curricula to foster internationalization: partnerships, foreign language learning, faculty members' initiatives, students' international or intercultural experiences, and interna- 
tionally focused learning outcomes and assessment. Conspicuously missing are supports needed to integrate international students so they can participate fully in university curricula and campus life.

\section{The Integration of Immigrant and International Learners}

Kreber (2009) argues that in moving from an elite to a mass form of higher education, postsecondary institutions face the challenge of supporting students who lack the cultural capital (Bourdieu, 2011) required to succeed without explicit language, culture, and skills support. At the same time, internationalization widens access to higher education to international students, who may come from elite or modest backgrounds and tend to share language and cultural barriers that can impede their ability to understand instructions, lectures, texts, and group discussions; participate in groups, class, and extracurricular activities; and integrate socially with their peers.

Higher education remains relatively open and affordable in Canada, making it a strategic detour for newcomers to learn the languages and culture(s) of their adopted country and to re/credential to Canadian professional or employment standards. Likewise, there is evidence that the federal government is shifting public-sector responsibilities for this critical role for higher education in settlement services to the postsecondary and private sectors: quotas for the Canadian Experience Class and the Provincial Nominee Program are expanding annually, while those for the Skilled Workers Class are shrinking (Table 1). The Canadian Experience Class, a relatively new initiative, permits international students who complete a degree and a year of employment in Canada to apply for permanent resident status. This focus on resettlement through higher education is a response to the challenges newcomers face in securing employment in Canada, which is perceived to be caused by gaps in Canadian work experience, language skills (Roddau, 2009) and workplace culture(s) (Laroche, 2003). For many EAP programs, the growing Canadian Experience Class has had the effect of blurring the lines between international and domestic ESL - two demographics that have traditionally been considered as having different needs.

Studies suggest that higher education institutions are ill equipped to address the broader workplace and community socialization needs of newcomers. Andrade (2006), for example, found immigrant and international students face significant obstacles and challenges in English language, culture, and academic skills, whereas Lewthwaite (1996) found a persistent lack of deep integration, a lack of intercultural communicative competence, and much loneliness and frustration. Inequities were also found for newcomers accessing professional programs (Schmidt, 2010). These challenges impact newcomers' academic success and ability to enter key professions and workplaces and represent a lost opportunity to foster the intercultural skills required by newcomers and native-born Canadians alike. 
Table 1

New Permanent Residents in Canada

\begin{tabular}{lrrrrrrr}
\hline Economic category & 2008 & 2009 & 2010 & 2011 & 2012 & $2013^{\mathrm{a}}$ & $2014^{\mathrm{b}}$ \\
\hline $\begin{array}{l}\text { Federal Skilled } \\
\text { Workers }\end{array}$ & 76,964 & 64,611 & 85,117 & 57,296 & 57,213 & 55,300 & 47,300 \\
$\begin{array}{l}\text { Quebec Skilled } \\
\text { Workers }\end{array}$ & 26,772 & 31,351 & 34,240 & 31,490 & 34,256 & 33,400 & 26,600 \\
$\begin{array}{l}\text { Business Immigrants } \\
\text { Provincial Nominee }\end{array}$ & 12,407 & 12,521 & 13,006 & 11,641 & 10,080 & 8,600 & 11,300 \\
Program & 22,418 & 30,378 & 36,428 & 38,420 & 40,899 & 42,000 & 46,800 \\
Live-in Caregivers & 10,511 & 12,454 & 13,909 & 11,247 & 9,012 & 9,300 & 17,500 \\
Canadian Experience & 0 & 2,544 & 3,917 & 6,027 & 9,359 & 10,000 & 15,000 \\
Class & & & & & & & \\
TOTAL & 149,072 & 153,498 & 186,913 & 156,121 & 160,819 & 158,600 & 164,500 \\
\hline
\end{tabular}

a Preliminary, ${ }^{\mathrm{b}}$ Projected; Government of Canada (2008, 2009, 2010, 2011, 2012, 2013)

\section{Disciplines vs. the World}

The disciplinary organization of higher education has persisted despite decades of critique (Kagan, 2009; Kreber, 2009; Prakash, 1999; Said, 1994; Snow, 1959). Developed around the turn of the 20th century, the dominant academic disciplines continue to resist addressing many key problems facing our collective life in a holistic manner, including an array of postcolonial, environmental, cultural, linguistic, and human migratory transformations. The reliance on individual faculty to design curriculum reinforces this reproductive bias in higher education, as faculty tend to be hired for disciplinary rather than professional or worldly expertise, and lack the resources, time, and ability to develop outcomes- or competency-based curricula to link knowledge to students' current or future working and personal lives. In exploring the role of academic disciplines in preparing 21st-century graduates, Kreber (2009) notes

the reason we are concerned with disciplines, and the learning within as well as beyond them, is precisely that we perceive a need to prepare our students for the complexities and unpredictability characterizing their future professional, civic and personal lives. (p. 3)

In the case of ESL in higher education, the problem has been a narrow focus on English language and literature rather than on its broad communicative application in target genres and contexts. In the 1970s and 1980s, English instructors tended to be hired for their graduate degrees in English literature, leading to a preoccupation with literary texts in instruction. The programs and profession have shifted to a preference for Teaching English to Speakers of Other Languages (TESOL) or Education degrees that focus more on communicative approaches to language instruction based on learner needs. 
However, the "old guard" dominates in some ESL programs and continues to be influenced by this earlier orientation, remaining unaware of or resistant to new conceptions of literacy such as multiliteracies (e.g., Cazden et al., 1996), situated literacies (e.g., Barton, Hamilton, \& Ivanic, 1999), and corpus-based genre studies (e.g., Biber, 2006; Biber \& Conrad, 2009a; Nesi \& Gardner, 2012) as well as the mismatch between ESL and post-ESL language use (e.g., Leki \& Carson, 1997).

\section{Outcomes- or Competency-Based Curricular Innovations}

Cumulatively, these challenges suggest the need to shift from a narrow disciplinary focus to a broader domain of interests, skills, and standards that is made possible by an outcomes-based curricular framework in higher education. The turn to outcomes-based curriculum as a vehicle for reform is mirrored in faculties in higher education (i.e., graduate attributes, professional accreditation requirements) and international initiatives, such as the current Assessment of Higher Education Learning Outcomes (AHELO) initiative of the Organisation for Economic Cooperation and Development (OECD), which distinguishes discipline-specific knowledge and skills from generic skills such as critical thinking, problem-solving, analytical reasoning, and written communication (Tamburri, 2013). Likewise, the AUCC (2009) identified the need for explicit international-related learning outcomes and assessments to internationalize Canadian universities. Yet, identifying standards and outcomes is not implicitly innovative: individual faculty members can place old wine in new bottles by merely translating longstanding curricular topics into the language of outcomes. A new approach is needed.

\section{The ESL Pathways Project}

The British Columbia ESL Pathways Project is an opportunity to meet these challenges through an innovative ESL program and curriculum to support newcomers in participating in overlapping academic, community, and workplace communities of practice. The program was conceived to serve newcomers, including international students, in various stages of settlement, all of whom intend to pursue higher education and/or the workplace in British Columbia. The project was awarded to Vancouver Community College, the largest ESL provider in $\mathrm{BC}$, by the provincial government with the stipulation that the program use the Canadian Language Benchmarks (Centre for Canadian Language Benchmarks [CCLB], 2012) and integrate the Essential Skills (Human Resources and Skills Development Canada [HRSDC], 2012), a set of nine skills derived from the OECD. These core competencies sit amongst a range of other language competencies (Figure 1) required in a number of different target communities of practice. 


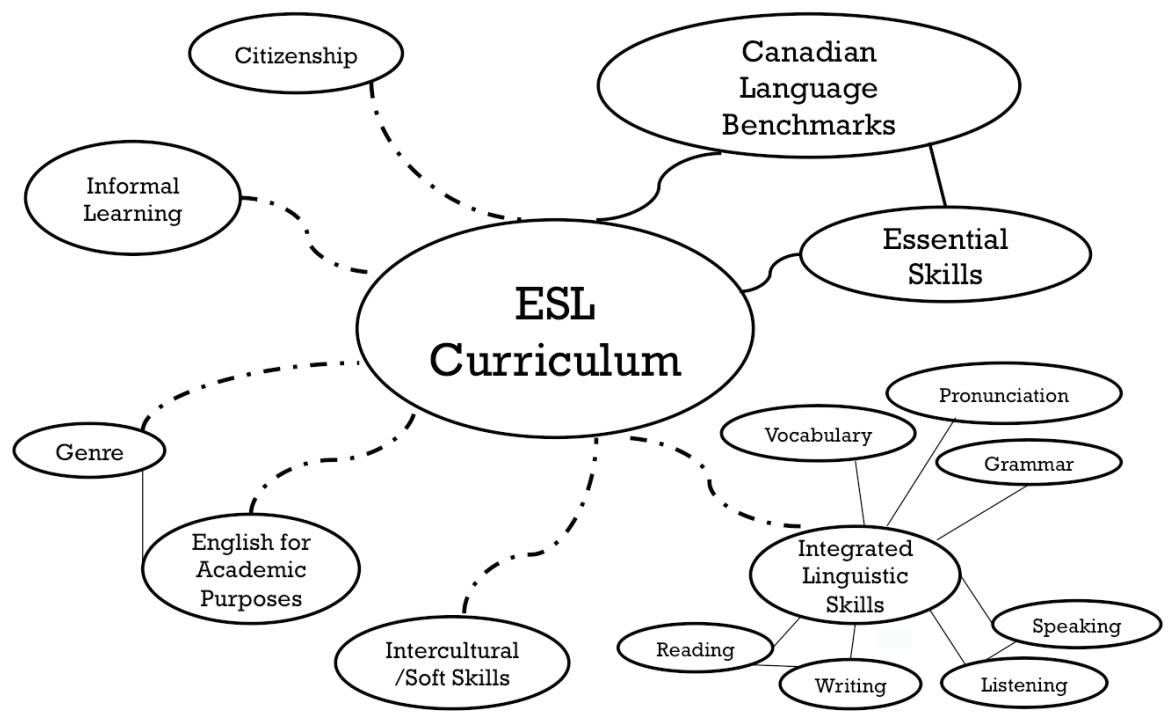

Figure 1: Map of Key Language Competencies

\section{Sociocultural and Activity Theory-}

Guiding ESL Pathways' Curriculum Development

Sociocultural theory (e.g., Lave \& Wenger, 1991) and activity theory (Leont'ev, 1978; Vygotsky, 1978) provided conceptual and analytical guidance in designing the ESL Pathways curriculum. These two related theories developed along separate lines from Vygotsky's $(1978,1986)$ perspectives that signs (i.e., language) and tools mediate human interaction with the world and, along with cultural, historical, and societal factors, shape human development. Based on his developmental research and perspectives from dialectical and historical materialism, Vygotsky (1978) argued that children learn to avail themselves of mediating artifacts (i.e., tools and language) during practical activity in order to fulfil their goals and, in doing so, internalize social speech and problem-solving capacity. Unlike behaviourist theories of the time that drew a direct link between stimulus (i.e., the object of cognition) and response (i.e., an organism's cognition), Vygotsky (1978) proposed a dialectical (i.e., mutually defining) relationship in which the individual (subject), by engaging tool and language use (mediating artifacts) in practical activity, transforms and is transformed by the world (object). The outcome is learning for the individual and change in the world. Engeström (2009) called this relationship the "first generation" of activity theory, noting

The basic unit of analysis (i.e., of cognition) now overcame the split between the Cartesian individual and the untouchable societal structure (...) the individual could no longer be understood without his 
or her cultural means (i.e., mediating tools and signs), and society could no longer be understood without the agency of individuals who use and produce artifacts (i.e., tools and language). (p. 54, italics ours)

\section{Sociocultural Theory}

Sociocultural theory (e.g., Rogoff \& Lave, 1984; Scribner \& Cole, 1981) drew on these Vygotskian (1978) perspectives from developmental psychology and also on cognitive anthropology and sociolinguistics to question the view of learning as something that transpires within a disembodied and decontextualized mind. Perhaps best known to English language educators is Lave and Wenger's (1991) concept of communities of practice, which emphasizes learning as mediated by the social and semiotic (i.e., language) context. Drawing on their research of situated apprenticeships (e.g., butchers, a chapter of Alcoholics Anonymous), they articulated a mechanism of learning as entailing social participation rather than the acquisition of a formal body of knowledge from a teacher. Importantly, this mechanism of legitimate peripheral participation describes how learners gain entrance to a new context (i.e., legitimate), begin as novices (i.e., peripheral), and engage in practice alongside those who share their goals (i.e., participation in a community of practice). Learning in a community of practice is holistic in the sense that boundaries between the learner, the community, and the environment co-inhere (Lave \& Wenger, 1991): "(it) implies emphasis on comprehensive understanding involving the whole person rather that 'receiving' a body of factual knowledge about the world; and on the view that agent, activity, and the world mutually constitute each other" (p. 32). Tacit in this perspective is the central importance of language, in that the ability to talk (and to be silent) in the manner of members of the community is crucial to full participation. The key to success is a situated engagement that allows the practitioner to develop a viable "identity in practice": undergoing a process of change and acquiring the products of learning (language, knowledge, identity) and hence garnering recognition as a full member.

Although justly critiqued in the sociocultural theory (e.g., Barton \& Tusting, 2005; Hager, 2005) and language socialization literature (e.g., Duff, 2010; Duranti, Ochs, \& Schieffelin, 2012), these sociocultural perspectives offer invaluable concepts with which to consider the interconnected domains of language, culture, and socialization required to realize social integration through education. Learning is conceived as the formation of a viable "identity in practice"; hence, curriculum can be thought of as that which is made available to participants through their participation in the structured social practices of the learning community rather than through the dissemination of knowledge-as-information from expert teachers via a plan for learning (Fuller, 2007). As such, the key challenge for curriculum developers is to support teachers and students in co-constructing a community of learners that engage in the practices, knowledge, and language of the target communities. 
By approximating the community of practice in the school's community of learners through the curriculum, novices begin developing an "identity in practice" and the language and knowledge this entails, within and beyond the classroom.

Although the field of ESL/EAP has long recognized the need for intersecting experiences in learning and actual communities of practice, it is challenging to fund, administer, and integrate these opportunities within the accelerated, heavy workloads of most EAP or ESL programs. There are many examples of learning experiences in target communities of practice linked to formal curricula. For example, Parks (2000) describes a program in which students in a work-related English program were able to serve tables as part of their curriculum, Riddiford (2011) overviews an ESL settlement curriculum for skilled immigrants with an integrated work placement, and Hummel (2013) details how service learning opportunities have been developed to serve this same need. In the ESL Pathways curriculum, in order to maintain a broad conception of target communities of practice across academic, work, and community contexts, experiential learning capstone courses are required for the intermediate and advanced certificates. Distinct from the ESL classes, these capstone courses entail the documentation of informal learning through an array of alternative forms of placements and participation. All activities in the experiential learning capstone courses are anchored in the theoretical foundations of Kolb's Experiential Learning Cycle (Kolb, 1984) and in Jarvis's (2004) model of learning processes. Jarvis proposes a number of different types of formal, informal, and nonformal learning, including formal education and training, ongoing learning in workplaces and community, learning in everyday life, self-directed learning, and incidental learning. Students in the program engage in their chosen community of practice; are guided through a cycle of doing, analyzing, and reflecting on their learning; and are given targeted support in using their English to accomplish their goals in different situations. Students' awareness of their learning process, the strategies learned, and the insights gained through navigating Canadian workplace, academic, and community contexts constitute the learning outcomes of the course rather than the accomplishment of their individually defined goals.

\section{Activity Theory}

The perspectives of sociocultural theory provided a way of conceptualizing the interconnected domains of language, culture, and socialization for the design of the ESL Pathways curriculum. It was activity theory; however, that enabled the curriculum designers to more fully frame and direct curriculum development so as to connect the classroom to target communities of practice (i.e., real-world activity). As described earlier, one takeaway from Vygotsky (1978) was that humans, by engaging tool and language use (mediating artifacts) in practical activity, transform and are transformed by the world (object). The outcome of this process for the individual is learning. Vygotsky 
(1978) also noted that language and tools - and the knowledge required for their continued use and modification - are passed between generations. Vygotsky's protégé Leont'ev (1978) elaborated on this notion by identifying the cultural, historical, and societal elements in activity systems (i.e., in communities of practice) that shape and are shaped by people and their cultural means (i.e., mediating tools and signs).

In Vygotsky's (1978) conception, the object of the activity can be an outward goal, a concrete purpose, or a conceptual understanding "at which the activity is directed and which is moulded or transformed into outcomes with the help of physical and symbolic, external and internal tools" (Engeström, 1993, p. 67) by an individual or group (subject). Leont'ev added that this process is contextualized and mediated by the community, rules, and division of labour (i.e., societal, historical, and cultural elements) at work in the activity system. The community of an activity system is the individuals or groups that share the mediating artifacts and whose agency is afforded or constrained through the division of labour or formal, informal, and technical rules (i.e., norms, conventions) of the community. All of these elements (subject, object, mediating tools, community, rules, division of labour) of an activity system or community of practice exist in mutually constituting relationships: they presuppose each other and have the potential to influence and transform one another. In this way, Leont'ev (1978) defined the complex, mutually defining relations that exist among subject, tools/signs, object, rules, community, and division of labour in an activity system (i.e., a target community of practice) and how they all contribute to outcomes for the activity system or the individual. Readers interested in learning more about activity theory will enjoy Roth and Lee (2007) and Roth (2009).

The first contribution of activity theory to the ESL Pathways curriculum was that it served as a lens for analyzing elements at work in an activity system (e.g., a target academic, workplace, or citizenship-related community of practice) and for guiding the creation of learning environments and experiences that allow students opportunities to developing "viable identities in practice." As discussed in the section that follows, this goal was realized through application of principles similar to those recommended by Jonassen and Rohrer-Murphy (1999) in employing activity theory to curriculum design. The second contribution of activity theory in the ESL Pathways curriculum model was to identify the set of clustered target activity units, tasks, and skills.

Activity is a cluster of social, rule-bound, and embodied actions, hierarchically structured into three discernible levels (Leont'ev, 1978) important for curriculum design (Figure 2). As embodiments of culture (activity level), they are formed through discrete, consciously enacted tasks (action level) that are constituted by automatic or semiconscious skills (operations level). In other words, although we experience an overall activity in terms of multiple conscious or intentional actions or events, they involve sequences and 
levels of tasks or skills with component micro-skills that are often performed in a semi- or unconscious manner by experts. Cultures and communities of practice are constituted by these activities, tasks, and skills, so it follows that inclusion is made possible by the mastery of skills and the appropriate performance of socially situated actions and interactions. Linguistic and cultural skills and habits mediate such performances; therefore, the tasks and underlying linguistic and cultural skills require explicit learning to develop.

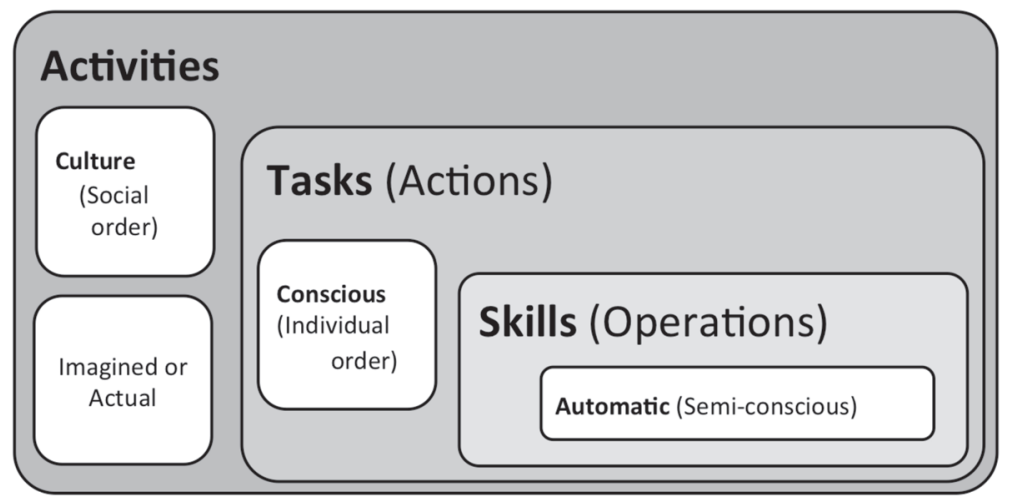

Figure 2: The Structure of Activities

(c) Province of British Columbia. All rights reserved. Reproduced with permission of the Province of British Columbia.

In this respect, the traditional curricular focus on disciplinary knowledge or, in the case of ESL, the English language as a structure or text are inadequate to instil the automatic habits involved in the completion of tasks required to perform the activities associated with membership in a community. The operations (skills) and action levels (tasks) of the structure shown in Figure 2 are not entirely new to ESL and are characterized in Rivers and Temperley's (1978) model as involving "skill getting" and "skill using." The innovation in this curriculum is that these first two levels of activity (skills and tasks, as identified here) are defined by and integrated into the higher-order "Activity" that is framed by the characteristics of the target community of practice (i.e., academic, workplace, or community).

This innovation to include the higher-order "activities" as the framework of units is in marked contrast to the existing tendency of task-based design to present tasks in an ad hoc fashion that reflect the logic of language development rather than the integrated language, sociocultural, and skill development required to participate within high-stakes communities of practice. The result of this tendency has meant that students in ESL are exposed to language in a functional manner, such as making a request of a coworker, but not necessarily to the situated use of language in complex social rituals, such as in workplace meetings. These functional abilities taught as 
isolated tasks may not be generalized, in turn, to the relevant sociocultural activities because of intercultural communicative obstacles such as differing cultural norms or unfamiliarity with the hierarchy and interactive rules of the communicative context. In contrast, if a unit is instead framed using an activity such as participating in workplace meetings, then the component tasks and skills are taught with that explicit context in mind. Furthermore, instructors are encouraged to provide opportunities to participate in the actual or approximate versions of the real activity and to use authentic materials in instruction. Such a framework was applied in this curriculum design, where extensive needs assessment and research identified both the target communities of practice and the component activities before identifying the actual tasks and skills to be taught within a unit. In this way, students' experiences in learning language more closely approximate the situated cognition that is required for successful participation within diverse communities of practice.

\section{Applying Activity Theory to Curriculum Design}

Activity theory proved useful in theoretically framing the ESL Pathways curriculum and defining the curriculum model. In addition, the curriculum team adapted Jonassen and Rohrer-Murphy's (1999) six-step approach for using activity theory in curriculum design for the context of the ESL Pathways Project:

- Clarify the purpose of activity system.

- Analyze the context.

- Analyze the activity system.

- Analyze the activity structure.

- Analyze tools and mediators.

- Analyze activity system dynamics.

\section{Clarify Purpose of Activity System: Developing a Project Mandate}

The ESL Pathways Project's mandate presented a unique opportunity to turn the lens away from traditional ESL frames of reference toward activities in the world - to post-ESL academic, work, and community contexts in which learners would be expected to function in the future. These real-world activities and needs were ascertained through a comprehensive examination of relevant current research, recognized standards, and "best" practices in ESL and adult education. Activity theory provided the framework to guide the curriculum design process conceptually and practically from within the domain of traditional ESL but also to extend its reach beyond it to post-ESL contexts. The project mandate focused on integrating Canadian Language Benchmark (CLB) language outcomes with academic skills, Essential Skills (workplace skills), and citizenship outcomes within a certificate-based ESL credential to be offered in higher educational contexts. 


\section{Analyze the Context:}

\section{Consulting and Performing an Environmental Scan}

The first task in the project was to conduct an environmental scan that surveyed ESL programs in higher education in western Canada regarding ESL placement, standards, assessment, and articulation processes. Most of these programs struggle individually to develop effective curriculum, standards, and assessment tools with inadequate resources or funds. The result is a loose curricular patchwork of outcomes and resources focusing on a narrow domain of academic competence that rarely addresses workplace or citizenship context, content, or skills. The environmental scans and consultations (i.e., learner focus groups, advisory boards, expert panels) continued throughout the curriculum development period. This process served to identify and define key program outcomes relating to citizenship, entry to jobs, postsecondary study, intercultural/soft skills, language, and essential skills. These program outcomes, in turn, were tied to the completion of each certificate (intermediate and advanced) and aligned with the course outcomes at each level to ensure that contextual needs were being addressed in particular assessed course or program outcomes.

\section{Analyze the Activity System: Identifying Target Activities and Tasks}

A revolving and developing set of five thematic areas were identified as the content focus (i.e., well-being, planning, information, culture, community) and specified according to the language level of the course units. For example, for the lowest CLB 5 Reading and Writing course, the "Information" theme was identified as "Advice," whereas at CLB 9, the highest level, the same "Information" theme was identified as "Scientific Literacy." These revolving themes were triangulated with 80 target activities to identify relevant tasks for each of the 80 curricular units. These themes also directly affected the selection of texts, where "texts" are understood to be multimedia and multimodal, and of a range of genres aimed at developing multiliteracy capacities.

Eighty target activities ( 8 for each of the 10 courses) were identified to serve as the focus for units of instruction, with subordinate tasks identified to guide actual instruction. The curriculum designers identified the activities based on their role in defining key target communities or practice in a range of academic, workplace, and personal contexts. The activities were identified using corpus linguistic data, other research, and professional documents (e.g., Service Canada's National Occupational Standards, Essential Skills Profiles), and labelled as gerund phrases (e.g., Planning a Research Report). In turn, a variety of standards, frameworks, and research were used to identify component tasks and to define the skills required to accomplish those tasks. These standards and research were translated into checklists for the purposes of curriculum development, to be used by developers to ensure coverage and holistic integration within activities (i.e., course units, courses, and the cur- 
riculum). Rather than being linear and hierarchical, this entire process was complex and iterative, requiring the various strands to be co-defined and crystallized into the structure of each activity or curriculum unit (Figure 3). The result was 80 units equally spread across 10 courses and five language levels, with an oral and a literacy course for each level. Therefore, with eight activities per course, one unit might take a week or two to complete. A sample of activities for the CLB Level 8 reading and writing is found in Table 2.

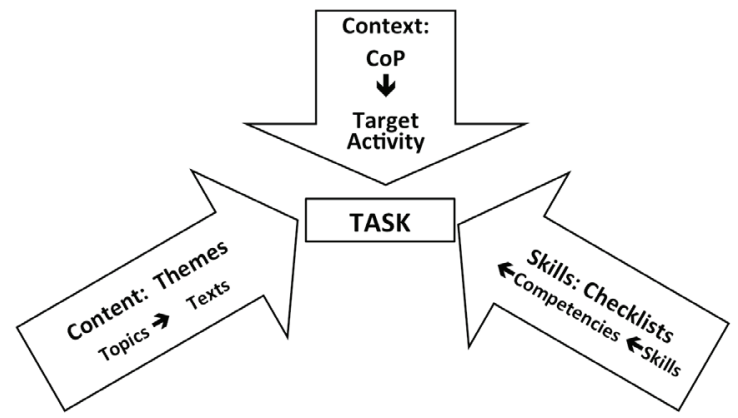

Figure 3: Co-defining Activities and Tasks

\section{Analyze the Activity Structure: \\ Developing an Integrated Outcomes Framework}

Rather than preparing students for only the language and subject matter of iconic English language tasks (e.g., the stuff of textbooks, essay assignments, lectures in an academic context), the curriculum developers used activity theory to go beyond traditional outcomes to prepare learners for the whole range of activities (formal, informal, nonformal) that compose and support broader situated, real-world competencies as well. Accordingly, the curriculum team identified the following relevant guiding characteristics of activity theory:

- Language and cultural skills (i.e., operations) are identified, presented, and integrated within tasks (i.e., actions).

- Language and cultural skills are presented on a sequence moving from explicit learning to implicit (more automated, task-embedded) application and use.

- Tasks are presented, integrated, and taught within activities (Figure 2).

- Activities derive from needs assessments that identify the requisite activities and component tasks required of learners within target communities of practice; therefore, all language and cultural skills and tasks taught derive from needs that learners can expect to face as they struggle to integrate within target communities of practice.

- An experiential learning capstone course is required at the intermediate and advanced certificate levels in which learners navigate a real-world target community of practice relevant to their goals. 


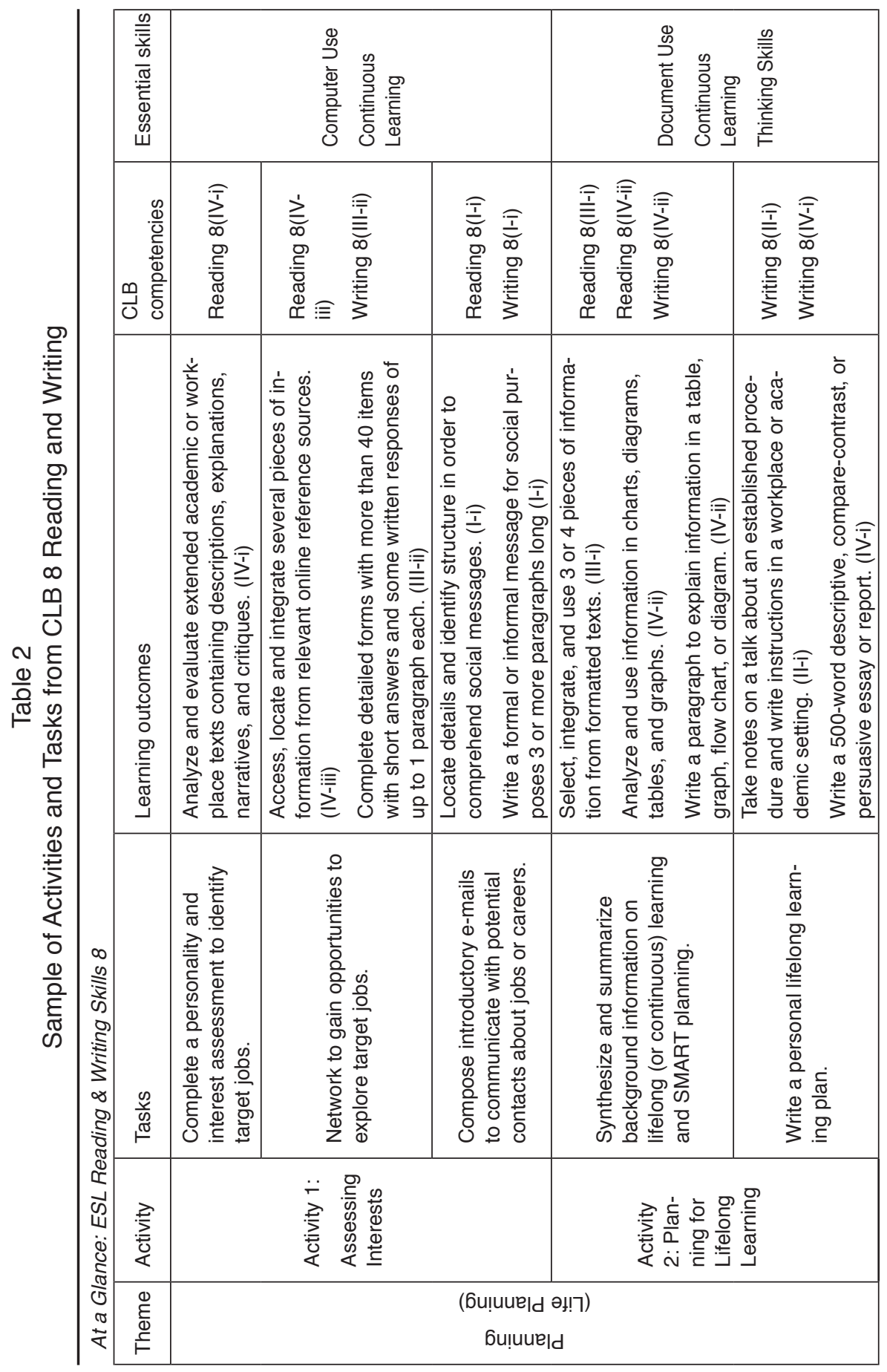




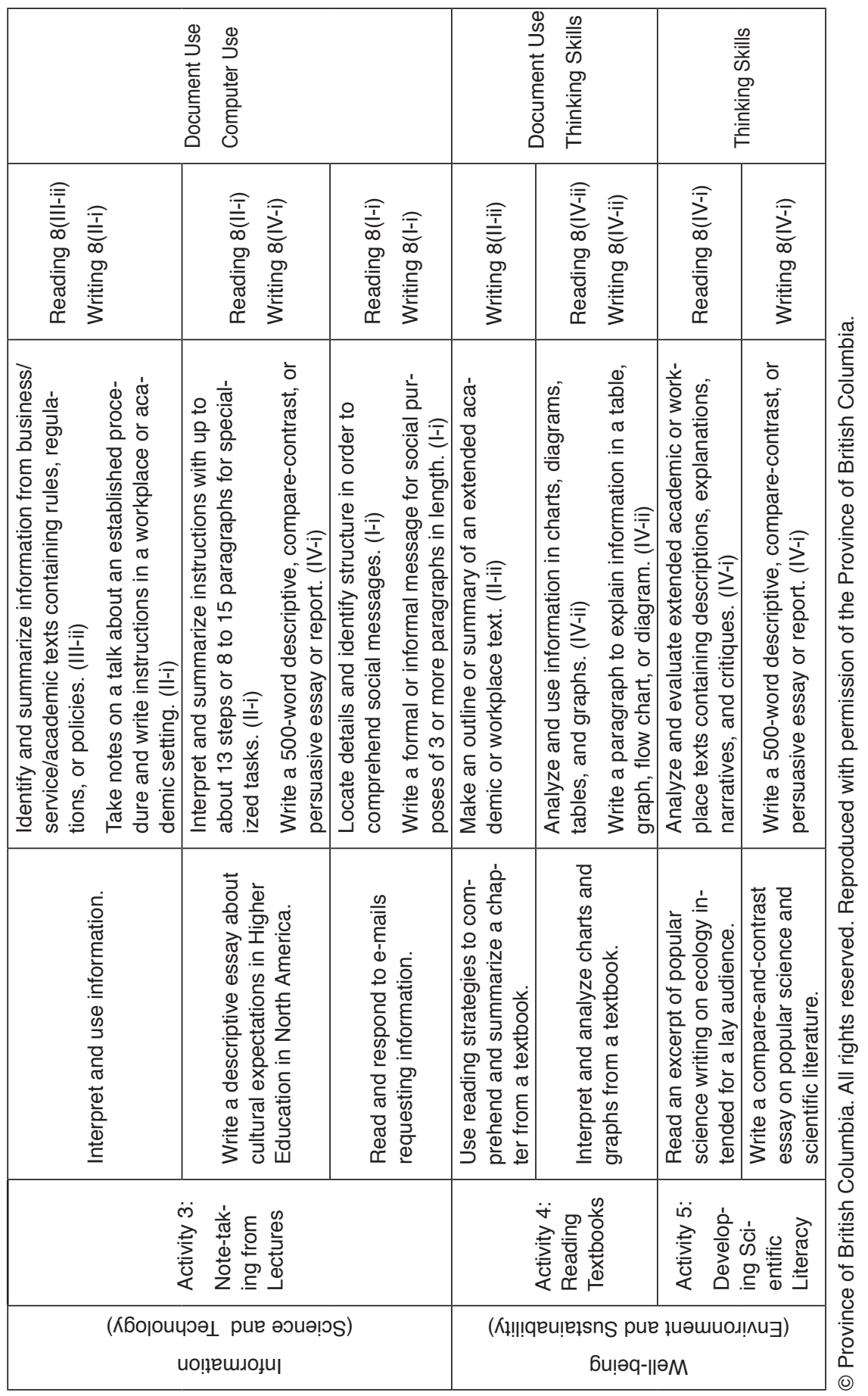




\section{Using Standards and Current Research}

In developing the activities (i.e., curricular units), the developers used a series of standards- or research-based checklists (Table 3). These checklists identified the competencies to be covered exhaustively across levels or certificates and the criteria for performance indicators to be used in assessment. The curriculum guidelines for each activity integrated these competencies and skills within tasks and activities, which were integrated in turn across the activities and course levels using authentic content and texts aimed at real-world contexts. Developers went through a careful, iterative process in which the context of the target activity and tasks, authentic content, and the required embedded competencies were co-defined, detailed, and triangulated to produce integrated units (Figure 3).

\section{Analyze Activity System Dynamics: Implementing and Evaluating the Curriculum}

The focus of this final stage is to assess the efficacy of the curriculum to support learners to acquire and gain experience in the target operations (i.e., skills) and actions (i.e., tasks) of the target activities of their real-world communities of practice. The minimum requirements for making trustworthy inferences about whether a curriculum is delivering what it promises requires, first, that the curriculum has evolved to the extent that it is stable and, second, that a formal program evaluation process is conducted according to best practices (Alkin, 2011). Unfortunately, neither condition was met in the field test due to the curriculum's stage of development and time and resource limitations. From September to December 2013, the 5-level, 10-course curriculum (12 weeks) and a capstone experiential learning curriculum (4 weeks each for the intermediate and advanced certificate) were field tested at Vancouver Community College (VCC), British Columbia, by 25 veteran ESL teachers from various VCC departments and other public postsecondary institutions, supported by 7 curriculum developers, 3 manager-facilitators, and 1 project manager.

The "field test" could be best be characterized as a "field development." The curriculum guidelines and lesson plans were well defined, while the authentic aural and written texts were largely selected but undeveloped and the portfolio-based learning assessment model was in place but without substantial assessment tool development. At the time of the "field test," the curriculum was emergent rather than stable, and, given this stage of evolution, directing resources at a program evaluation was judged to be premature. Nevertheless, the discussions from four student focus groups (18 students total) conducted by impartial outside facilitators were recorded and transcribed, and individual reflections were collected from each of the 20 teachers in the core curriculum at the end of the field test in De- 
Table 3

Checklists Drawn from Standards and Current Research

\begin{tabular}{|c|c|c|}
\hline $\begin{array}{l}\text { Competency / } \\
\text { Checklist }\end{array}$ & Description & References \\
\hline $\begin{array}{l}\text { Language } \\
\text { Competencies }\end{array}$ & - Canadian Language Benchmarks, CLB 5-9 & CCLB, 2012 \\
\hline Essential Skills & $\begin{array}{l}\text { - OECD-derived skills identified by Human Re- } \\
\text { sources and Skills Development Canada (i.e., Docu- } \\
\text { ment Use, Computer Use, Thinking Skills, Working } \\
\text { with Others Skills, and Continuous Learning Skills) } \\
\text { - Did not include Essential Skills of numeracy or } \\
\text { literacy }\end{array}$ & HRSDC, 2012 \\
\hline Genre & $\begin{array}{l}\text { - Academic, workplace genres identified by expert } \\
\text { review corpus-genre studies } \\
\text { - Genres appear as embedded competencies for } \\
\text { materials development, lesson planning, teaching } \\
\text { for broad exposure relevant to target contexts. }\end{array}$ & $\begin{array}{l}\text { Biber, 2006; Biber \& } \\
\text { Conrad, 2009; Nesi \& } \\
\text { Gardner, } 2012\end{array}$ \\
\hline $\begin{array}{l}\text { English for } \\
\text { Academic } \\
\text { Purposes }\end{array}$ & $\begin{array}{l}\text { - BALEAP (British Association of Lecturers in Eng- } \\
\text { lish for Academic Purposes) competency framework } \\
\text { for teachers of EAP, selected EAP reference books, } \\
\text { identified by expert review }\end{array}$ & $\begin{array}{l}\text { BALEAP, 2008; refer- } \\
\text { ence (e.g., Hyland, } \\
\text { 2006; McCarter \& } \\
\text { Jakes, 2009; Nuttall, } \\
\text { 2005) }\end{array}$ \\
\hline $\begin{array}{l}\text { Vocabulary / } \\
\text { Vocabulary } \\
\text { Strategies }\end{array}$ & $\begin{array}{l}\text { - Derived partly from the CLB grammatical compe- } \\
\text { tencies and profiles of ability } \\
\text { - Academic word list and mid-frequency vocabulary } \\
\text { and targets identified for all levels }\end{array}$ & $\begin{array}{l}\text { Bachman, 1990; } \\
\text { Bachman \& Palmer, } \\
\text { 2010; CCLB, 2012; } \\
\text { Coxhead, 2006; Na- } \\
\text { tion, 2006, 2008 }\end{array}$ \\
\hline Grammar & $\begin{array}{l}\text { - Identified through expert review using a corpus } \\
\text { linguistic study and CLB grammatical knowledge } \\
\text { identified }\end{array}$ & $\begin{array}{l}\text { CCLB, 2012; Conrad } \\
\text { \& Biber, } 2009\end{array}$ \\
\hline $\begin{array}{l}\text { Intercultural } \\
\& \text { soft skills }\end{array}$ & $\begin{array}{l}\text { - Cognitive, affective, and behavioural skills support- } \\
\text { ing effective and appropriate interaction in a variety } \\
\text { of cultural contexts } \\
\text { - Key employability skills identified through expert } \\
\text { review of work-oriented publications }\end{array}$ & $\begin{array}{l}\text { AACU, 2010; Ben- } \\
\text { nett, 2008; Con- } \\
\text { ference Board of } \\
\text { Canada, 2012; } \\
\text { Kandra, Sewell, } \\
\text { \& Nyamari, 2011; } \\
\text { Noorani, } 2011\end{array}$ \\
\hline Citizenship & $\begin{array}{l}\text { - Understanding of the rights and responsibilities of } \\
\text { citizenship and skills and knowledge required for } \\
\text { civic engagement }\end{array}$ & $\begin{array}{l}\text { Government of Al- } \\
\text { berta, } 2005\end{array}$ \\
\hline $\begin{array}{l}\text { Textual, } \\
\text { Functional, } \\
\text { Sociolinguistic, } \\
\text { \& Strategic }\end{array}$ & $\begin{array}{l}\text { - Derived from the CLB, who drew from other } \\
\text { sources and articulated these competencies by skill } \\
\text { and by level band (i.e., reading, writing, listening, } \\
\text { and speaking; CLB, } 1-4,5-8 \text {, and 9-12) }\end{array}$ & $\begin{array}{l}\text { originating from Bach- } \\
\text { man, 1990; Bachman } \\
\text { \& Palmer, 2010; } \\
\text { CCLB, 2012; Celce- } \\
\text { Murcia, Dornyei, \& } \\
\text { Thurrell, } 1995\end{array}$ \\
\hline
\end{tabular}

(c) Province of British Columbia. All rights reserved. Reproduced with permission of the Province of British Columbia. 
cember 2013. The relevant sections from the transcripts, notes, and reflections were coded inductively and carefully examined for themes that might provide an early glimpse of the efficacy of the ESL Pathways curriculum. The relevant sections relate to the responses to the following student focus group questions:

- How did the ESL Pathways program prepare you for (a) community, (b) workplace, (c) academic?

- Were the materials in the ESL Pathways program "different" compared to materials you have used in other ESL classes you have taken in Canada? How? Can you give some examples?

- If you could add/cut one thing from the ESL Pathways program, what would it be?

The question of interest from the teacher reflection was

- The role of the teacher is different in the ESL Pathways curriculum compared to the role of the teacher in traditional ESL classes. What required the most significant shift in your teaching approach? How did this shift change over time?

Preliminary findings from the focus groups and teacher reflections are briefly presented here with the understanding that the data set is small and students in the focus groups came from different levels and had disparate learning goals. As such, well-grounded claims cannot be made at this point about the efficacy of the curriculum. The preliminary findings are

- There was a general appreciation among the teachers and students that the ESL Pathways curriculum was well organized and effectively and holistically integrated to a greater extent than previous ESL curricula in which they had taught or learned.

- A majority of students, particularly those with workplace and community goals, felt that the curriculum "matched real life" to a great extent, thanks specifically to the authentic and practical focus of the activities and the explicit teaching of intercultural skills and awareness (four students secured employment through the curriculum activities or the experiential learning course).

- A slim majority of students with academic goals questioned whether the curriculum effectively prepared them for study, specifically in the area of academic writing where they requested more. Having sufficient time for academic writing was also a concern for teachers of the advanced certificate.

- There was a moderate awareness among students that the approach to grammar in the curriculum was not structured enough.

- There was a general awareness that proper coverage of the material in the curriculum was difficult considering the time constraints; a few students expressed a preference for deeper learning in fewer activities. 
- There was a resoundingly positive response among students and teachers alike to the almost exclusive use of authentic materials and to the variety of aural and written genres and literacies covered compared to previous ESL experiences.

Revisions to the materials and the portfolio-based learning assessment were conducted between January 2014 and March 2014 followed by a second curriculum piloting.

\section{Conclusion}

This article has described the application of sociocultural and activity theory, research, recognized standards, and best practices to the process of creating an innovative CLB-, outcomes-, task/activity-, and content-based curriculum that unites the three goals of language learning in community, workplace, and academic study. The approach outlined in this article is recommended for inspiring and guiding the development of innovative curricula that address real challenges in the sector, namely: to facilitate the integration of international and immigrant learners in higher education, work, and community; to address the disciplinary rigidity that exists in some ESL faculties; and to move to outcomes-based curricula. The ESL Pathways curriculum is offered as an exemplar of an innovative curriculum that continues to evolve to meet these challenges.

Given our experience of adding a layer of research or applied research to this project and our opportunity to systematically reflect on the results, we now offer specific comments on issues, strengths, and limitations in applying activity theory in curriculum design in ESL or other fields.

\section{Research and Funding Limitations}

The opportunity to access a pool of public resources to support a curriculum design process and product for use across various postsecondary institutions is rare. Without a dedicated team and ample resources, it is difficult to complete a sufficiently thorough needs assessment and research phase to identify and design pedagogical tasks and activities that approximate real-world activities in target communities of practice. In this respect, it may be unrealistic and overly ambitious to make this an aim or an expectation in contexts where funding, expertise, or institutional capacity is limited.

\section{ESL/EAP Teacher Selection}

To be effective, activity-based instructional design depends as much or more on the experience and knowledge of teachers as on the formal curriculum. There is a need in EAP and work-related ESL for more instructors with experience in the target communities of practice of learners or experience collaborating with instructors in the target discipline or profession. 


\section{Access to Target Communities of Practice or Authentic Contexts}

Optimally, to be consistent with activity theory, the pedagogical tasks and learners would scaffold learners progressively to participate in real-world activities in target communities of practice. This requires a blurring or extension of the classroom into the world and vice versa, which can present significant financial, scheduling, and administrative challenges to programs. The model of an experiential capstone course or learning opportunity in this curriculum is an example of one such initiative, which many programs may not be in a position to offer.

\section{Recognizing the Disjuncture Between Pedagogical and Real Activities}

It is easy to delude oneself as a teacher that authentic, real-world pedagogical tasks somehow equate to full participation in a community of practice. Therefore, there is an inevitable disjuncture between student behaviour and activities in a community of learning and those in a community of practice. For example, students in EAP/ESP (English for Specific Purposes) courses do not necessarily respond to EAP/ESP teachers as they would to instructors in an academic discipline or workplace (Beer, 2000; Raymond \& Parks, 2002).

\section{Accommodating Learner Agency}

To a great extent, activity theory offers a robust extension of learner-centred practices that shifts the responsibility and diversity in learning from the instructor's plan to the learner's plan. This suggests that learners may have different preferences in performing on the pedagogical-to-real-world task spectrum. Some may prefer to focus on the essay as a way to learn to write, even though it is a genre not emphasized in their target communities of practice. Students' individual attitudes, motives, and preferences strongly impact how they perform in a classroom task or activity. This diversity in learning outcomes is reflected in the phrase "Same task, different activities" (Coughlan \& Duff, 1994).

In general, the project has succeeded in producing an organized, holistically integrated curriculum capable of drawing students closer to their target communities of practices of postsecondary study, work, and community. A fruitful line of inquiry for future field-testing may lie in exploring the capacity of this curriculum to help students access and succeed in academic communities of practice. Feedback from students and teachers suggests that the explicit focus on academic and mid-frequency words, intercultural skills, and genre is beneficial for students. While the general model and approach of the curriculum is positive, enhancing the capacity and utility of ESL Pathways in its future evolution will involve grappling with the focus, breadth, and depth of the learning in the curriculum's activities so that students with disparate needs can transition and succeed in their target communities of practice. Important in maintaining the original intent of the ESL Pathways curriculum is to continue linking learners' education with real-world post-ESL activities by 
maintaining the holistic integration of skills needed to accomplish tasks and activities, continuing to refine the curriculum at the materials level, and by continuing to fostering real-world connections in the core course and more substantially in the capstone experiential learning course.

With respect to implementation, future research will need to focus on the ease with which the planned curriculum is translated into the lived curriculum of ESL classrooms in higher educational contexts. An initial stage-wise implementation process is recommended to support the staggered delivery of the curriculum and program across voluntary institutions in BC, beginning with Vancouver Community College. Another key topic for future research concerns the efficacy of the curriculum to prepare students to participate in the target activities and real-world communities of practice. Finally, the role of informal learning needs to be tracked, as it is being assessed and documented through a parallel experiential learning inventory, which could offer interesting data on how to bridge informal and formal curricular objectives and experiences.

\section{Acknowledgements}

An initial draft of this article was presented at the SCUTREA/CRLL Conference (Standing Conference on University Teaching and Research in the Education of Adults/Centre for Research in Lifelong Learning) in Glasgow, Scotland, in 2013 with funding support from Vancouver Community College, the University of British Columbia, and the University of the Fraser Valley. In addition, we would like to thank the Government of British Columbia (Ministry of Jobs, Tourism, and Skills Training) with support from the Government of Canada (Citizenship and Immigration Canada), who funded the curriculum design process. Finally, we would like to acknowledge the contributions of other members of the curriculum design team, the senior project management, and the wonderful instructors and students who participated in the pilot implementation of the ESL Pathways Curriculum at Vancouver Community College in Vancouver, BC, Canada. A hearty thanks to all!

\section{The Authors}

Chris Campbell, PhDc, is a language and STEM education researcher, teacher, and curriculum developer. He served as senior curriculum developer in the ESL Pathways Project at Vancouver Community College. He has also served as a classroom assessment coordinator and lecturer in the University of British Columbia's (UBC's) K-12 teacher education program and as an educational assessment and evaluation consultant to UBC Engineering in their curriculum improvement and accreditation initiatives.

Seonaigh MacPherson, PhD, is Associate Professor and Head of the Department of Adult Education at the University of the Fraser Valley in British Columbia. She served as Curriculum Lead in the ESL Pathways Project and as an ELSA-Net Coordinator serving ELSA/LINC teachers. She has consulted widely on a range of ESL curriculum projects and for the Centre for Canadian Language Benchmarks on the 2010 Canadian Language Benchmarks.

Tanis Sawkins (DipTESL, MA) is on the faculty at Vancouver Community College. She currently works as a curriculum designer and leader in the ESL Pathways project. Her interests include the Recognition of Prior Learning (RPL), Occupation Specific Language Teaching (OSLT), and immigrant integration issues. Tanis sits on the Board of Directors for the Centre for Canadian Language Benchmarks. 


\section{References}

Alkin, M. C. (2011). Evaluation essentials: From A to Z. New York, NY: Guilford Press.

Andrade, M. S. (2006). International students in English-speaking universities: Adjustment factors. Journal of Research in International Education, 5(2), 131-154.

Association of American Colleges and Universities (AACU). (2010). VALUE rubrics. Retrieved from http://www.aacu.org/value/rubrics/index.cfm

Association of Universities and Colleges of Canada (AUCC). (2009). Internationalization of the curriculum: A practical guide to support Canadian universities' efforts. Retrieved from http://www. aucc.ca/wp-content/uploads/2011/07/curriculum-primer-2009-03-31-e.pdf

Bachman, L. F. (1990). Fundamental considerations in language testing. Oxford, UK: Oxford University Press.

Bachman, L., \& Palmer, A. (2010). Language assessment in practice. Oxford, UK: Oxford University Press.

Barton, D., Hamilton, M., \& Ivanic, R. (1999). Situated literacies: Theorizing reading and writing in context. New York, NY: Routledge.

Barton, D., \& Tusting, K. (Eds.). (2005). Beyond communities of practice: Language, power, and social context. New York, NY: Cambridge University Press.

Beer, A. (2000). Diplomats in the basement: Graduate engineering students and intercultural communication. In P. Dias \& A. Paré (Eds.), Transitions: Writing in academic and workplace settings (pp. 61-88). Cresskill, NJ: Hampton Press.

Bennett, J. M. (2008). Transformative training: Designing programs for cultural learning. In M. A. Moodian (Ed.), Contemporary leadership and intercultural competence: Understanding and utilizing cultural diversity to build successful organizations (pp. 95-110). Thousand Oaks, CA: Sage.

Biber, D. (2006). University language: A corpus-based study of spoken and written registers. Philadelphia, PA: John Benjamins.

Biber, D., \& Conrad, S. (2009). Register, genre, and style. New York, NY: Cambridge University Press.

Bourdieu, P. (2011). The forms of capital (1986). In I. Szeman \& T. Kaposy (Eds.), Cultural theory: An anthology (pp. 81-93). Chichester, UK: Wiley-Blackwell.

British Association of Lecturers in English for Academic Purposes (BALEAP). (2008). Competency framework for teachers of English for Academic Purposes. Retrieved from http://www.baleap.org. uk/media/uploads/pdfs/teap-competency-framework.pdf

Cazden, C., Cope, B., Fairclough, N., Gee, J., Kalantzis, M., Kress, G., ... Nakata, M. (1996). A pedagogy of multiliteracies: Designing social futures. Harvard Educational Review, 66(1), 60-92.

Celce-Murcia, M., Dornyei, Z., \& Thurrell, S. (1995). Communicative competence: A pedagogically motivated model with content specifications. Issues in Applied Linguistics, 6(2), 5-35.

Centre for Canadian Language Benchmarks (CCLB). (2012). Canadian Language Benchmarks: English as a second language for adults. Retrieved from http://www.cic.gc.ca/english/pdf/pub/ language-benchmarks.pdf

Conference Board of Canada. (2012). Employability skills 2000+. Retrieved from http://www.conferenceboard.ca/topics/education/learning-tools/employability-skills.aspx

Conrad, S., \& Biber, D. (2009). Real grammar: A corpus-based approach to English. Boston, MA: Pearson.

Coughlan, P., \& Duff, P. (1994). Same task, different activities: Analysis of a SLA [second language acquisition] task from an Activity Theory perspective. In J. Lantolf \& G. Appel (Eds.), Vygotskian perspectives on second language research (pp. 173-193). Norwood, NJ: Ablex.

Coxhead, A. (2006). Essentials of teaching academic vocabulary. Boston, MA: Cengage Learning.

Dias, P. (2000). Writing classrooms as activity systems. In P. Dias \& A. Paré (Eds.), Transitions: Writing in academic and workplace settings (pp. 11-29). Cresskill, NJ: Hampton Press.

Dias, P., Freedman, A., Medway, P., \& Paré, A. (Eds.). (1999). Worlds apart: Acting and writing in academic and workplace contexts. Mahwah, NJ: Lawrence Erlbaum. 
Duff, P. A. (2010). Language socialization into academic discourse communities. Annual Review of Applied Linguistics, 30, 169-192.

Duranti, A., Ochs, E., \& Schieffelin, B. B. (2012). The handbook of language socialization. Malden, MA: Wiley-Blackwell.

Ellis, R. (2009). Task-based language teaching: Sorting out the misunderstandings. International Journal of Applied Linguistics, 19(3), 221-246.

Engeström, Y. (1993). Developmental studies of work as a test bench of Activity Theory: The case of primary care medical practice. In S. Chaiklin \& J. Lave (Eds.), Understanding practice: Perspectives on activity and context (pp. 64-103). Cambridge, UK: Cambridge University Press.

Engeström, Y. (2009). Expansive learning. In K. Illeris (Ed.), Contemporary theories of learning: Learning theorists, in their own words (pp. 53-73). New York, NY: Routledge.

Fuller, A. (2007). Critiquing theories of learning and communities of practice. In J. Hughes, N. Jewson, \& L. Unwin (Eds.), Communities of practice: Critical perspectives (pp. 19-29). Abingdon, UK: Routledge.

Government of Alberta. (2005). Social studies: Kindergarten to Grade 12: Program rationale and philosophy. Edmonton, AB: Alberta Education.

Government of Canada. (2008, 2009, 2010, 2011, 2012, 2013). Annual report to Parliament on immigration. Ottawa, ON: Citizenship and Immigration Canada.

Hager, P. (2005). Current theories of workplace learning: A critical assessment. In N. Bascia, A. Cumming, A. Datnow, K. Leithwood, \& D. Livingstone (Eds.), International handbook of educational policy (pp. 829-846). Norwell, MA: Springer.

Hedge, T. (2000). Teaching and learning in the language classroom. Oxford, UK: Oxford University Press.

Human Resources and Skills Development Canada (HRSDC). (2012). Literacy and essential skills. Retrieved from http://www.hrsdc.gc.ca/eng/jobs/les/index.shtml

Hummel, K. M. (2013). Target language community involvement: Second language linguistic, self- confidence and other perceived benefits. Canadian Modern Language Review, 69(1), 65-90.

Hyland, K. (2006). English for academic purposes: An advanced resource book. New York: Routledge.

Jarvis, P. (2004). Adult education and lifelong learning: Theory and practice. New York, NY: RoutledgeFalmer.

Jonassen, D. H., \& Rohrer-Murphy, L. (1999). Activity Theory as a framework for designing constructivist learning environments. Educational Technology Research and Development, 47(1), 61-79.

Kagan, J. (2009). The three cultures: Natural sciences, social sciences, and the humanities in the 21st century-Revisiting C. P. Snow. Cambridge, UK: Cambridge University Press.

Kandra, M., Sewell, T., \& Nyamari, J. (2011). A young professional's guide to career success using soft skills. ISACA Journal, 1, 1-5. Retrieved from http://www.isaca.org/Journal/ Past-Issues/2011/Volume-1/Pages/A-Young-Professionals-Guide-to-Career-Success-UsingSoft-Skills.aspx

Kolb, D. A. (1984). Experiential learning: Experience as the source of learning and development. Englewood Cliffs, NJ: Prentice Hall.

Kreber, C. (2009). Supporting student learning in the context of diversity, complexity and uncertainty. In C. Kreber (Ed.), The university and its disciplines: Teaching and learning within and beyond disciplinary boundaries (pp. 3-18). New York, NY: Routledge.

Laroche, L. (2003). Managing cultural diversity in technical professions. Burlington, MA: ButterworthHeinemann.

Lave, J., \& Wenger, E. (1991). Situated learning: Legitimate peripheral participation. New York, NY: Cambridge University Press.

Leki, I., \& Carson, J. (1997). "Completely different worlds": EAP and the writing experiences of ESL students in university courses. TESOL Quarterly, 31(1), 39-69.

Leont'ev, A. N. (1978). Activity, consciousness, and personality. Englewood Cliffs, NJ: Prentice-Hall.

Lewthwaite, M. (1996). A study of international students' perspectives on cross-cultural adaptation. International Journal for the Advancement of Counselling, 19(2), 167-185. 
McCarter, S., \& Jakes, P. (2009). Uncovering EAP: Teaching academic writing and reading. New York, NY: MacMillan.

Nation, I. S. P. (2006). How large a vocabulary is needed for reading and listening? Canadian Modern Language Review, 63(1), 59-82.

Nation, I. S. P. (2008). Teaching vocabulary: Strategies and techniques. Boston, MA: Heinle.

Nesi, H., \& Gardner, S. (2012). Genres across the disciplines: Student writing in higher education. Cambridge, UK: Cambridge University Press.

Noorani, N. (2011). Nine soft skills no immigrant should be without! Canadian Immigrant. Retrieved from http://canadianimmigrant.ca/work-and-education/nine-soft-skills-no-im

Nuttall, C. (2005). Teaching reading skills in a foreign language. London, UK: MacMillan.

Parks, S. (2000). Same task, different activities: Issues of investment, identity, and use of strategy. TESL Canada Journal, 17(2), 64-88.

Prakash, G. (1999). Another reason: Science and the imagination of modern India. Princeton, NJ: Princeton University Press.

Raymond, P. M., \& Parks, S. (2002). Transitions: Orienting to reading and writing assignments in EAP and MBA contexts. Canadian Modern Language Review, 59(1), 152-180.

Riddiford, N. (2011). Helping skilled migrants into employment: The workplace communication program. In J. Macalister \& I. S. P. Nation (Eds.), Case studies in language curriculum design (pp. 72-81). New York, NY: Routledge.

Rivers, W. M., \& Temperley, M. S. (1978). A practical guide to the teaching of English as a second or foreign language. New York, NY: Oxford University Press.

Roddau, S. H. (2009, October). Language barriers to employment faced by internationally educated professionals (IEPS). Paper presented at the National Metropolis Conference, Calgary, Alberta. Retrieved from http://canada.metropolis.net/events/metropolis_presents/languagematters. html

Rogoff, B., \& Lave, J. (1984). Everyday cognition: Its development in social context. Cambridge, MA: Harvard University Press.

Roth, W.-M. (2009). Cultural-historical Activity Theory: Towards a social psychology from first principles. History and Philosophy of Psychology Bulletin, 21(1), 6-22.

Roth, W.-M., \& Lee, Y.-J. (2007). "Vygotsky's neglected legacy": Cultural-historical Activity Theory. Review of Educational Research, 77(2), 186-232.

Said, E. W. (1994). Representations of the intellectual. New York, NY: Random House.

Schmidt, C. (2010). Systemic discrimination as a barrier for immigrant teachers. Diaspora, Indigenous, and Minority Education, 4(4), 235-252..

Scribner, S., \& Cole, M. (1981). The psychology of literacy. Cambridge, MA: Harvard University Press.

Snow, C. P. (1959). The two cultures. London, UK: Cambridge University Press.

Swales, J. (1990). Genre analysis: English in academic and research settings. Cambridge, UK: Cambridge University Press.

Swales, J. (1996). Teaching the conference abstract. In E. Ventola \& A. Mauranen (Eds.), Academic writing: Today and tomorrow (pp. 45-59). Helsinki, Finland: Helsinki University Press.

Swan, M. (2005). Legislation by hypothesis: The case of task-based instruction. Applied Linguistics, 26(3), 376-401.

Tamburri, R. (2013, February). Trend to measure learning outcomes gains proponents: Canadian universities have been slow to move but may have to keey up with the international trend, observers say. University Affairs. Retrieved from http://www.universityaffairs.ca/trend-tomeasure-learning-outcomes-gains-proponents.aspx

Vygotsky, L. S. (1978). Mind in society: The development of higher psychological processes. Cambridge, MA: Harvard University Press.

Vygotsky, L. S. (1986). Thought and language. Cambridge, MA: MIT Press. 